\title{
Low adaptive potential for tolerance to ethynylestradiol, but also low toxicity, in a grayling population (Thymallus thymallus)
}

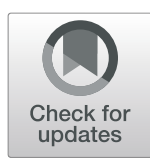

\author{
Lucas Marques da Cunha, Diane Maitre and Claus Wedekind ${ }^{*}$ (B)
}

\begin{abstract}
Background: The presence of a novel pollutant can induce rapid evolution if there is additive genetic variance for the tolerance to the stressor. Continuous selection over some generations can then reduce the toxicity of the pollutant but also deplete the additive genetic variance for the tolerance and thereby slow down adaptation. One common pollutant that has been ecologically relevant for some time is 17alpha-ethynylestradiol (EE2), a synthetic compound of oral contraceptives since their market launch in the 1960s. EE2 is typically found in higher concentrations in rivers than in lakes. Recent experimental work revealed significant genetic variance for the tolerance to EE2 in two lake-spawning salmonid species but no such variance in river-spawning brown trout. We used another river-spawning salmonid, the European grayling Thymallus thymallus, to study the toxicity of an ecologically relevant concentration of EE2. We also used a full-factorial in vitro breeding design and singly rearing of 1555 embryos and larvae of 40 sib groups to test whether there is additive genetic variance for the tolerance to this pollutant.
\end{abstract}

Results: We found that exposure to EE2 reduced larval growth after hatching, but contrary to what has been found in the other salmonids, there were no significant effects of EE2 on embryo growth and survival. We found additive genetic variance for embryo viability, i.e. heritability for fitness. However, there was no significant additive variance for the tolerance to EE2.

Conclusions: Our findings support the hypothesis that continuous selection has reduced the toxicity of EE2 and depleted genetic variance for tolerance to this synthetic stressor.

Keywords: Chemical pollution, Rapid evolution, Salmonidae, Estrogen, Embryo survival, Larval growth, Additive genetic variance

\section{Background}

Chemical pollution is one of the anthropogenic pressures that can threaten salmonid populations [1-3]. Salmonids are particularly exposed to such micropollutants during embryogenesis, because they typically have large eggs and long embryo developmental times, both of which enable greater uptake of ambient micropollutants during this sensitive stage $[4,5]$. One of the most common pollutant is the synthetic estrogen $17 \alpha$-ethynylestradiol (EE2) that is an active ingredient of most oral contraceptive pill formulations and has higher stability and estrogenic potency

\footnotetext{
*Correspondence: claus.wedekind@unil.ch

Department of Ecology and Evolution, Biophore, University of Lausanne, 1015 Lausanne, Switzerland
}

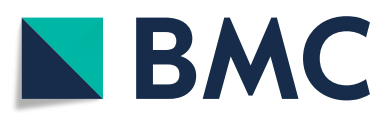

(อ) The Author(s). 2019 Open Access This article is distributed under the terms of the Creative Commons Attribution 4.0 International License (http://creativecommons.org/licenses/by/4.0/), which permits unrestricted use, distribution, and reproduction in any medium, provided you give appropriate credit to the original author(s) and the source, provide a link to the Creative Commons license, and indicate if changes were made. The Creative Commons Public Domain Dedication waiver (http://creativecommons.org/publicdomain/zero/1.0/) applies to the data made available in this article, unless otherwise stated. often detected in rivers that carry sewage treatment effluents $[8,9]$, and concentrations around $1 \mathrm{ng} / \mathrm{L}$ have often been measured [10]. Dissolved in water, its half-life times can be over 3 months under laboratory conditions [11], but photodegradation and the presence of co-absorbing organic matter can reduce half-life times to one or few days [12]. We therefore expect river-spawning salmonid fish to be typically exposed to higher concentrations of EE2 than lake-spawning salmonids [8, 10, 13].

Exposure to ecologically relevant concentrations of EE2 can affect gene expression in adult fish, especially in their liver and gonads [14] and in the kidneys [15]. Such EE2-induced changes affect germ cell proliferation and hormone production [14] and reduce fertility 
and survival of some fish [16, 17]. When applied over several years, ecologically relevant EE2 concentrations in the water can significantly change ecosystems by affecting reproduction and mean body condition in various fish [18, 19]. If these effects are sex-specific (see discussion below), population sex ratios could be affected, too [20]. Embryos and larvae may be even more susceptible to the toxicity of EE2 than adults [21]. For example, single spikes of only $2 \mathrm{pg}$ EE2 added to embryos in $2 \mathrm{~mL}$ containers induced significant mortality and delayed hatching in two whitefish species [22]. However, such toxicity effects seem species dependent. The embryos of two other salmonid fish, the Atlantic salmon (Salmo salar) [23] and the brown trout (Salmo trutta) [11] seemed more tolerant to low concentrations of EE2, i.e. they showed lower EE2-induced mortality and lower reduction in growth (see below). These differences among salmonids are not sufficiently understood yet.

EE2 was a novel pollutant to freshwater ecosystems when the contraceptive pill was launched to the market in the 1960s. The presence of this stressor could have induced rapid evolution in some exposed salmonid populations that happened to have additive genetic variation for the tolerance to this new type of pollution [24, 25]. Continuous selection over several generations would then be expected to reduce the toxicity of EE2 but also deplete the genetic variance for its tolerance and thereby slow down adaptation [26]. If so, we would predict on average lower toxicity of, and lower genetic variation for the tolerance to, EE2 in river-spawning than in lakespawning salmonids.

Recent experimental studies on salmonids seem to support this prediction. On the one hand, embryos of two lake-spawning salmonid species, the whitefish Coregonus palaea from Lake Geneva (Switzerland) and C. albellus from Lake Brienz (Switzerland), displayed increased mortality and delayed hatching after exposure to low or high concentrations of EE2 [22]. For the lowest concentration tested in Brazzola et al. [22], a single aqueous exposure to $1 \mathrm{ng} / \mathrm{L}$ led to increases in mortalities of 3 and 13\% points, respectively. Both populations also displayed significant additive genetic variance for EE2-induced embryo mortality [22]. On the other hand, embryos of two river-spawning salmonid species, the brown trout and the Atlantic salmon, showed no or weak responses to the same ecologically relevant EE2 concentration. Marques da Cunha et al. [11] found EE2 to reduce embryo survival by only $0.9 \%$ points, and they found no additive genetic variance for the tolerance to EE2 in seven genetically distinct populations. Duffy et al. [23] found no EE2-induced mortality in embryos and larvae of Atlantic salmon. They also studied vitellogenin gene transcription and plasma concentrations and found this precursor egg protein to be significantly affected only in embryos exposed to EE2 concentrations that may be too high to be ecologically relevant. However, further examples are necessary to test whether lakespawning and river-spawning salmonids differ systematically in their reaction to EE2.

Here we focus on another river-spawning salmonid of another subfamily, the European grayling (Thymallus thymallus). We chose a grayling population that spawns in the River Aare in the city of Thun (Switzerland) and uses the river and the Lake Thun as feeding grounds. The population has continuously declined since the 1970s and is currently protected $[27,28]$. In response to the population decline, conservation authorities have complemented their supportive breeding program based on wild-caught individuals with a broodstock based on F1 offspring from the wild population. The broodstock's genetically effective population size $\left(\mathrm{N}_{\mathrm{e}}\right)$ is about a third of the wild population's $\mathrm{N}_{\mathrm{e}}$ (Marques da Cunha, Mobley, Maitre, de Guttry, Wedekind, in preparation). Because this broodstock population has been recently established and consists of F1 s only, and because population size is only weakly related to quantitative genetic variation if a population decline is recent and not too extreme [29,30], we could avoid sampling the protected wild population and use samples from the captive population instead.

Selmoni et al. [31] found in 5 of the 40 sibgroups that are studied here (see below) that an aqueous exposure of grayling embryos to $1 \mathrm{ng} / \mathrm{L}$ EE2 caused significant changes in gene expression. These changes were strongly dependent on genetic sex and developmental stage. During the embryonic stage when whole embryos were analysed, nearly 400 genes were found to be differentially expressed in males in response to EE2, but only 15 genes in females. Around hatching and towards the end of the yolk sac period when only heads were analysed, exposure to EE2 caused differential expression of about 20,000 and 10,000 genes, respectively, with a similar number of genes being up- or downregulated. However, only females showed such strong reactions to EE2. The reactions in males were much weaker ( 1 and 4 genes, respectively, based on $\mathrm{q}<0.15$ ). New and continuous exposure to EE2 during juvenile stages then delayed the onset of sex differentiation [31], but it remained unclear whether the one-dose exposure to EE2 during the embryonic stage that induced the strong responses in the transcriptomes also reduced embryo or larval viability and growth (as in whitefish [22]) or had little effects (as in brown trout [11] and Atlantic salmon [23]).

Here we study a much larger sample and concentrate on the following questions: (i) is the toxicity of EE2 in a river-spawning grayling more comparable to the lakespawning or to river-spawning salmonids, and (ii) is there additive genetic variance for tolerance to EE2 in 
the grayling population we study? High toxicity and high additive genetic variance would suggest that the population still has the potential for rapid evolution in response to this type of pollution, while high toxicity and low additive genetic variance would mean that pollution by EE2 can be one of the factors that currently contribute to the population decline [28].

\section{Methods}

Adult grayling were sampled from a recently established captive population (cantonal Fischereistützpunkt Kandersteg, Bern, Switzerland) that consists of F1 of the population studied in Wedekind et al. [28]. Eight females (dams) and 10 males (sires) were stripped for their gametes and then returned to the population. These gametes were used for in vitro fertilizations in two full-factorial blocks of 4 dams $\times 5$ sires each to produce 40 half-sib families (Fig. 1). The water used for fertilizations and the rearing of embryos was chemically standardized according to the OECD guideline No. 203 [32] and aerated before use. The freshly fertilized eggs were left undisturbed for $2 \mathrm{~h}$ and then transported to a climate chamber $\left(\right.$ at $7{ }^{\circ} \mathrm{C}$ ) where they were washed and singly distributed to 24-well plates (Greiner Bio-One, Kremsmünster, Austria) filled with $1.8 \mathrm{~mL}$ of autoclaved standardized water, as in von Siebenthal et al. [33] $\left(\mathrm{N}_{\text {eggs }}=10,789\right)$. After one week, eggs without visible embryo were discarded, leaving in total 7397 eggs with embryos (on average 185 embryos per sibgroup, range 89-307). These

\begin{tabular}{|c|c|c|c|c|c|}
\hline $\begin{array}{c}\text { breeding } \\
\text { block 1 }\end{array}$ & 5493 & 5494 & 5495 & 5496 & 5497 \\
\hline BBE & 31 & 21 & 25 & 23 & 28 \\
\hline BBF & 37 & 36 & 40 & 34 & 37 \\
\hline BBG & 49 & 48 & 53 & 52 & 51 \\
\hline BBH & 63 & 66 & 62 & 54 & 52 \\
\hline breeding & 5504 & 5505 & 5506 & $S 507$ & $S 508$ \\
\hline block 2 & & & & & \\
\hline BBK & 33 & 35 & 34 & 38 & 35 \\
\hline BBL & 32 & 42 & 31 & 39 & 38 \\
\hline BBM & 23 & 31 & 34 & 24 & 36 \\
\hline BBN & 37 & 33 & 40 & 38 & 40 \\
\hline
\end{tabular}

Fig. 1 Two full-factorial breeding blocks crossing 4 females (rows) with 5 males (columns) each. Individuals were raised singly in 24well plates until $40 \mathrm{dpf}$ (day post fertilization). The figure gives the total numbers of embryos that were EE2- or control-treated embryos were assigned to different studies: in total 250 of 5 half-sib families were used for gene expression analyses [31], another sample of 3580 embryos was exposed or sham-exposed to a pathogen to study the genetic aspects of pathogen resistance (Marques da Cunha, Mobley, Maitre, de Guttry, Wedekind, in preparation). A further sample of in total $1555 \mathrm{em}$ bryos was assigned to the present study (Fig. 1). After embryo and larval performance had been recorded (see below), a mixed sample of these differently treated larvae and of the remaining ones were pooled and further raised in aquaria to study sex differentiation [31, 34]. All remaining samples were euthanized with an overdose $(1 \mathrm{~mL} / \mathrm{L})$ of Koimed Sleep (Ethylenglycolmonophenylether; Koimed, Ulmiz, Switzerland).

The EE2 and control stock solutions were prepared as in Marques da Cunha et al. [11]. Briefly, an EE2 stock solution of $10 \mathrm{ng} / \mathrm{L}$ made of analytical $17 \alpha$-ethynylestradiol (Sigma-Aldrich, USA) and 0.004\% absolute ethanol (VWR International, USA) was prepared for the EE2 treatment, and a control stock solution of $0.004 \%$ ethanol only was prepared for the sham treatment. Both stock solutions were made with autoclaved standardized water [32]. Two weeks after fertilization, 8 embryos per family were sham-treated, i.e. $0.2 \mathrm{~mL}$ of the control stock solution was added to each well (final water volume $=2 \mathrm{~mL}$ / well). All remaining embryos received $0.2 \mathrm{~mL}$ of the EE2 stock solution (i.e. a dose of 2 pg EE2) for a concentration of $1 \mathrm{ng} / \mathrm{L}$ and a final volume of $2 \mathrm{~mL}$ per well. After exposure, the embryos were regularly examined and mortality was recorded. In the last two days before the expected start of hatching (i.e., 27 and 28 days post fertilization) incubation temperature was raised from $7^{\circ} \mathrm{C}$ to $10^{\circ} \mathrm{C}$ and $11.5^{\circ} \mathrm{C}$, respectively, in order to reduce variance in the timing of hatching.

Each plate containing a freshly hatched larva was scanned on the day of hatching and 8 days later (Epson, Perfection V37, Japan). The larval body length and yolk sac dimensions (length and width) were measured from these scans using ImageJ (http://rsb.info.nih.gov/ij/). Yolk sac volume was calculated as described in Jensen et al. [35]. Of the in total 1347 hatchlings, 124 (9.2\%) were accidently lost after hatching. These were all EE2treated individuals from 16 of the 40 families (range 417 per family), i.e. each experimental cell (Fig. 1) was still well represented for the measurements after hatching. Larval growth was calculated as the difference between length after 8 days and at hatching, and yolk sac consumption as the difference between yolk sac volume at hatching and 8 days later.

Embryo and larval survival were analysed as binomial response variables in generalized linear mixed models (GLMM). Timing of hatching, hatchling length, larval growth, and yolk sac consumption were analysed in 
linear mixed models (LMM) as continuous response variables. Treatment and parental effects on embryo phenotypes were investigated with treatment (EE2 or control) as a fixed effect and sire and dam as random effects. Sire and dam effects are nested in breeding block, but entering breeding block as further random or fixed effect did not change any of the conclusions (results not shown). The significance of each effect was assessed by comparing models including or lacking the term of interest to a reference model. Akaike's information criteria (AIC) were used as measures of model fit and model complexity, and likelihood ratio tests (LRT) were used to compare models. All the mixed-effects models were fitted with the lme4 $\mathrm{R}$ package [36] and all the statistical analyses were performed in R [37].

\section{Results}

Total embryo survival until hatching was $86.6 \%$ (controls: $87.8 \%$, EE2 exposed: $86.3 \%$ ), and total larval survival during the first 8 days after hatching was $82.2 \%$ (controls: 82.5\%, EE2 exposed: 82.1\%). Maternal sib groups varied strongly in all measures of survival and growth (dam effects in Tables 1 and 2). Exposure to EE2 by itself caused no significant effects on embryo survival and growth (Table 1; Fig. 2a-c) and had no significant effects on larval survival (Table 2a; Fig. 2d). However, exposure to EE2 affected the timing of hatching differently depending on maternal sib groups ( $\mathrm{t} x \mathrm{~d}$ interaction in Table $1 \mathrm{~b}$ ) and reduced larval growth after hatching (Table 2b, c; Fig. 2e, f).

Paternal sib groups differed in embryo survival, revealing additive genetic variance for fitness (Table 1a). Sire identity also affected the timing of hatching (Table 1b) but had no significant effects on larval mortality (Table 2a) nor on embryo or larval growth (Table 1c, Table $2 b, c)$. Importantly, paternal sib groups did not significantly differ in response to EE2, i.e. there was no evidence for additive genetic variance in the tolerance to EE2 ( $\mathrm{x}$ s interaction terms in Tables 1 and 2).

\section{Discussion}

The two main questions of the present study were: Is an ecologically relevant exposure to EE2 toxic to embryos and larvae of a population of river-spawning grayling, and is there additive genetic variance for the tolerance to EE2 in this population, i.e. does the population currently have a potential to rapidly adapt to this type of pollution? The first question is relevant even if the toxicity of EE2 has been demonstrated in many other fish taxa (e.g. [38-41]), because (i) the study population is declining for unknown reasons and a lack of an evolutionary response to toxicity could be contributing to the problem, and (ii) the chemical pollution of freshwater habitats that has happened since the market launch of
Table 1 Treatment and parental effects on embryo traits. Likelihood ratio tests on mixed model regressions on (A) embryo survival, (B) timing of hatching, and (C) length at hatching. Models including or lacking the term of interest were compared to reference models (in bold) to determine the significance of the effect tested

\begin{tabular}{llllll}
\hline Model & Effect tested & AlC & d.f. & $x^{2}$ & $P$ \\
\hline $\begin{array}{lllll}\text { (A) Embryo survival } \\
\mathbf{t}+\mathbf{d}+\mathbf{s}\end{array}$ & & 1166 & 4 & & \\
$\mathrm{~d}+\mathrm{s}$ & $\mathrm{t}$ & 1165 & 3 & 0.7 & 0.42 \\
$\mathrm{t}+\mathrm{s}$ & $\mathrm{d}$ & 1219 & 3 & 55.0 & $<\mathbf{0 . 0 0 1}$ \\
$\mathrm{t}+\mathrm{d}$ & $\mathrm{s}$ & 1173 & 3 & 8.8 & $\mathbf{0 . 0 0 3}$ \\
$\mathrm{t}+\mathrm{t} \mid \mathrm{d}+\mathrm{s}$ & $\mathrm{t} \times \mathrm{d}$ & 1169 & 6 & 1.1 & 0.57 \\
$\mathrm{t}+\mathrm{d}+\mathrm{t} \mid \mathrm{s}$ & $\mathrm{t} \times \mathrm{s}$ & 1173 & 6 & $<0.1$ & 1.0 \\
(B) Timing of hatching & & & & \\
$\mathbf{t}+\mathbf{d}+\mathbf{s}$ & & 2953 & 5 & & \\
$\mathrm{~d}+\mathrm{s}$ & $\mathrm{t}$ & 2951 & 4 & $<0.1$ & 1.0 \\
$\mathrm{t}+\mathrm{s}$ & $\mathrm{d}$ & 3038 & 4 & 86.7 & $<\mathbf{0 . 0 0 1}$ \\
$\mathrm{t}+\mathrm{d}$ & $\mathrm{s}$ & 2955 & 4 & 4.0 & $\mathbf{0 . 0 4}$ \\
$\mathrm{t}+\mathrm{t} \mid \mathrm{d}+\mathrm{s}$ & $\mathrm{t} \times \mathrm{d}$ & 2913 & 7 & 44.7 & $<\mathbf{0 . 0 0 1}$ \\
$\mathrm{t}+\mathrm{d}+\mathrm{t} \mid \mathrm{s}$ & $\mathrm{t} \times \mathrm{s}$ & 2956 & 7 & 1.2 & 0.55 \\
(C) Length at hatching & & & & \\
$\mathbf{t}+\mathbf{d}+\mathbf{s}$ & & 1664 & 5 & & \\
$\mathrm{~d}+\mathrm{s}$ & $\mathrm{t}$ & 1663 & 4 & 0.3 & 0.56 \\
$\mathrm{t}+\mathrm{s}$ & $\mathrm{d}$ & 1688 & 4 & 25.8 & $<\mathbf{0 . 0 0 1}$ \\
$\mathrm{t}+\mathrm{d}$ & $\mathrm{s}$ & 1662 & 4 & 0.1 & 0.81 \\
$\mathrm{t}+\mathrm{t} \mid \mathrm{d}+\mathrm{s}$ & $\mathrm{t} \times \mathrm{d}$ & 1664 & 7 & 3.2 & 0.20 \\
$\mathrm{t}+\mathrm{d}+\mathrm{t} \mid \mathrm{s}$ & $\mathrm{t} \times \mathrm{s}$ & 1667 & 7 & 0.8 & 0.65 \\
\hline $\mathrm{t}$ & & & &
\end{tabular}

$t$ treatment, $s$ sire, $d$ dam

Significant $p$-values are emphasized in bold

the contraceptive pill, i.e. during more than 5 decades, could have led to adaptation and hence to reduced toxicity in some fish. The answer to the latter question may help us to better understand if pollution by EE2 has induced rapid evolution because, in our study population, the period of exposure is likely to span around 10 to 15 generations, i.e. there could have been enough time for evolution to deplete any genetic variance for tolerance to EE2 that the population could have had at the beginning of the exposure. Moreover, these questions are of ecotoxicological relevance $[10,42,43]$ because standard ecotoxicological testing often ignores potential taxonspecific toxicities [44].

Regarding our first main question: We found a statistically non-significant increase in mortality of $1.5 \mathrm{pp}$. for embryos and $0.4 \mathrm{pp}$. for larvae. These effect sizes seem comparable to the observed increase in embryo mortality of $0.9 \mathrm{pp}$. in brown trout that was only significantly different from zero because of an extra-ordinary large sample size ( $N=7302$ singly raised embryos) [11]. In whitefish, 
Table 2 Treatment and parental effects on larval traits. Likelihood ratio tests on mixed model regressions on (A) larval survival, (B) larval growth, and (C) yolk sac consumption of embryos exposed to EE2 or sham treated. Models including or lacking the term of interest were compared to reference models (in bold) to determine the significance of the effect tested

\begin{tabular}{|c|c|c|c|c|c|}
\hline Model & Effect tested & AIC & d.f. & $x^{2}$ & $P$ \\
\hline \multicolumn{6}{|c|}{ (A) Larval survival } \\
\hline$t+d+s$ & & 678 & 4 & & \\
\hline$d+s$ & t & 679 & 3 & 2.6 & 0.11 \\
\hline$t+s$ & $d$ & 996 & 3 & 320.2 & $<0.001$ \\
\hline$t+d$ & s & 678 & 3 & 2.1 & 0.14 \\
\hline$t+t \mid d+s$ & $t \times d$ & 680 & 6 & 2.2 & 0.33 \\
\hline$t+d+t \mid s$ & $\mathrm{t} \times \mathrm{s}$ & 682 & 6 & 0.3 & 0.86 \\
\hline \multicolumn{6}{|c|}{ (B) Larval growth } \\
\hline$t+d+s$ & & 778 & 5 & & \\
\hline$d+s$ & $\mathrm{t}$ & 781 & 4 & 4.5 & 0.03 \\
\hline$t+s$ & $d$ & 840 & 4 & 64.0 & $<0.001$ \\
\hline$t+d$ & s & 780 & 4 & 3.4 & 0.06 \\
\hline$t+t \mid d+s$ & $t \times d$ & 782 & 7 & 0.1 & 0.93 \\
\hline$t+d+t \mid s$ & $\mathrm{t} \times \mathrm{s}$ & 784 & 7 & $<0.1$ & 1.0 \\
\hline \multicolumn{6}{|c|}{ (C) Yolk sac consumption } \\
\hline$t+d+s$ & & 1479 & 5 & & \\
\hline$d+s$ & $\mathrm{t}$ & 1481 & 4 & 4.0 & 0.05 \\
\hline$t+s$ & $d$ & 1579 & 4 & 101.8 & $<0.001$ \\
\hline$t+d$ & s & 1477 & 4 & $<0.1$ & 1.0 \\
\hline$t+t \mid d+s$ & $t \times d$ & 1483 & 7 & $<0.1$ & 1.0 \\
\hline$t+d+t \mid s$ & $t \times s$ & 1483 & 7 & $<0.1$ & 1.0 \\
\hline
\end{tabular}

$t$ treatment, $s$ sire, $d$ dam

Significant $p$-values are emphasized in bold

the EE2-induced increase in embryos mortality was significant and around 3\% points (pp) in C. palaea [22] and around $13 \mathrm{pp}$. in C. albellus [22].

With the observed low mortality, the question of whether there is EE2-induced sex-specific mortality in grayling cannot be solved yet. The study population suffers from a skewed sex ratio (more males than females [28]) that seems not due to EE2-induced sex reversal $[28,31]$ but rather caused by sex-specific mortality [45]. It is still possible that there are sex-specific susceptibilities to combined effects of EE2 and other environmental stressors. Other types of environmental stressors such as microbes [39], temperature variations [27], or other micropollutants $[40,46]$ could interact with the effects of EE2 and thereby amplify its toxicity [47, 48]. Therefore, single-factor laboratory studies like ours are likely to underestimate the ecotoxicological relevance of EE2 in the wild.

While EE2- and sham-exposed grayling embryos hatched at similar size, exposure to EE2 reduced larval growth and consumption of yolk sac after hatching by about $4 \%$ each during the first 8 days after hatching. We therefore conclude that EE2 is toxic to grayling at early developmental stages. Such a reduction in growth was predicted from recent analyses of physiological reactions to EE2 in Atlantic salmon [23, 49] but was not observed in brown trout [11]. One possible explanation for this apparent discrepancy between brown trout and grayling larvae is that hatching was not induced in the study on brown trout [11] but induced by an increase in temperature in the present study on grayling. Under the given conditions, EE2-exposed brown trout embryos hatched later and at smaller size than sham-exposed ones, while, in the present study on grayling, no treatment-related difference in the timing of hatching nor on hatchling size could be observed. If growth rate after hatching is dependent on larval size and developmental stage, such differences in the experimental protocols could be responsible for the apparent differences in treatment effects on growth rates. However, in both cases, the combined effects of EE2 on embryo and larval development would be expected to delay the emergence from gravel at the end of the yolk sac stage and could even lead to smaller body sizes at emergence. Time to emergence, and body size at emergence, is likely to be linked to fitness in salmonids because larvae that emerge earlier and larger than others may face less competition for resources (e.g. feeding territory) and are more prone to outcompete their late emerging counterparts [50,51].

Regarding our second main question: Because grayling males do not provide any parental care, significant sire effects on offspring traits reveal additive genetic variance in full-factorial breeding experiments [26]. The dam effect then represents a combination of additive genetic variance and maternal environmental effects [26]. In salmonids, maternal environmental effects comprises characteristics such as egg size [50] and compounds that females allocate to their eggs (e.g. [52-56]). We found strong direct maternal effects on every offspring trait that we measured, and a dam x EE2 interaction on the timing of hatching. We conclude that maternal sib groups reacted differently to exposure to EE2. However, these maternal effects seem to be mainly due to maternal environmental effects [57], because we found no significant additive genetic variance for tolerance to EE2 pollution in any of the analysed traits.

No significant additive genetic variance could potentially be due to a type II error (false negative). However, such an error is unlikely here because (i) our analysis is based on a large sample size (1555 singly-reared embryos) and 40 sib groups, (ii) our sample revealed overall additive genetic variance (i.e. significant sire effects) on embryo mortality and the timing of hatching, (iii) a parallel study (Marques da Cunha, Mobley, Maitre, de 

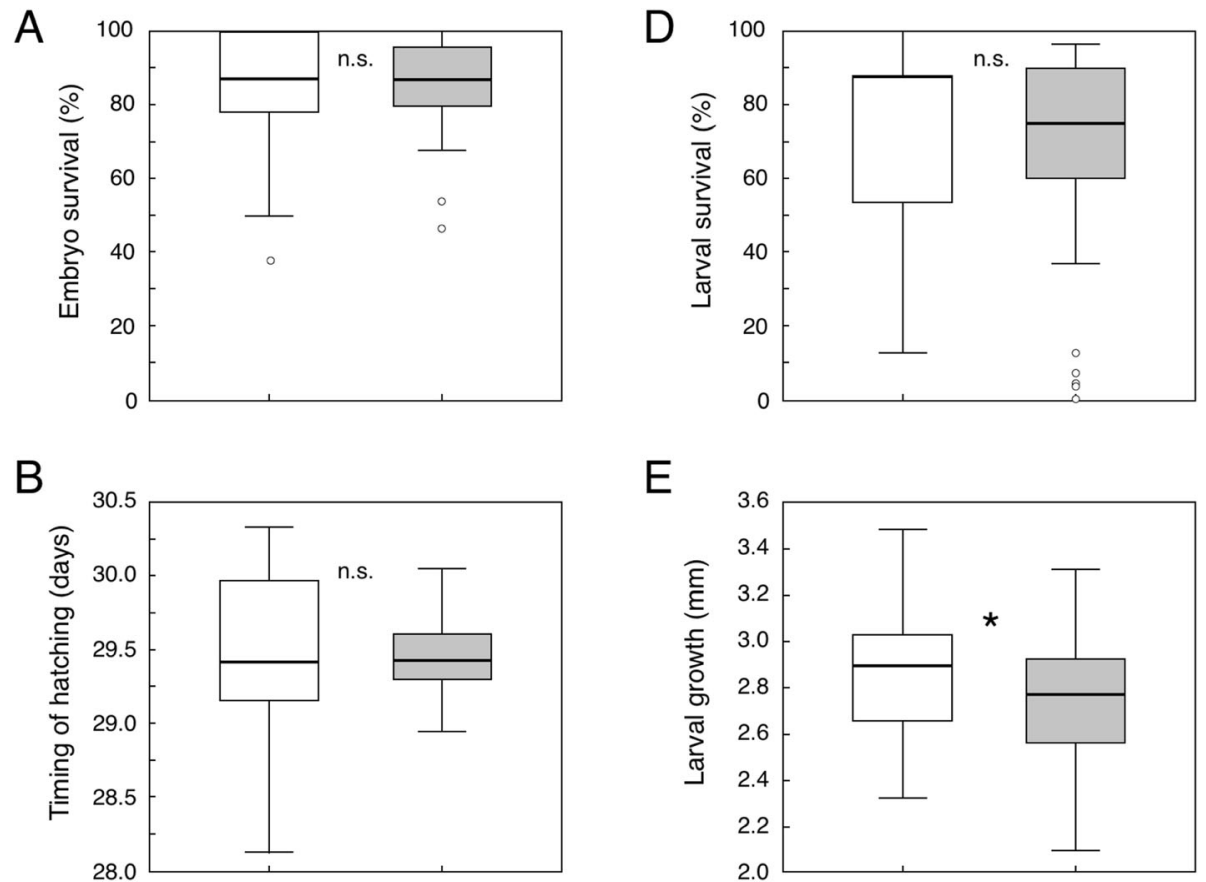

E
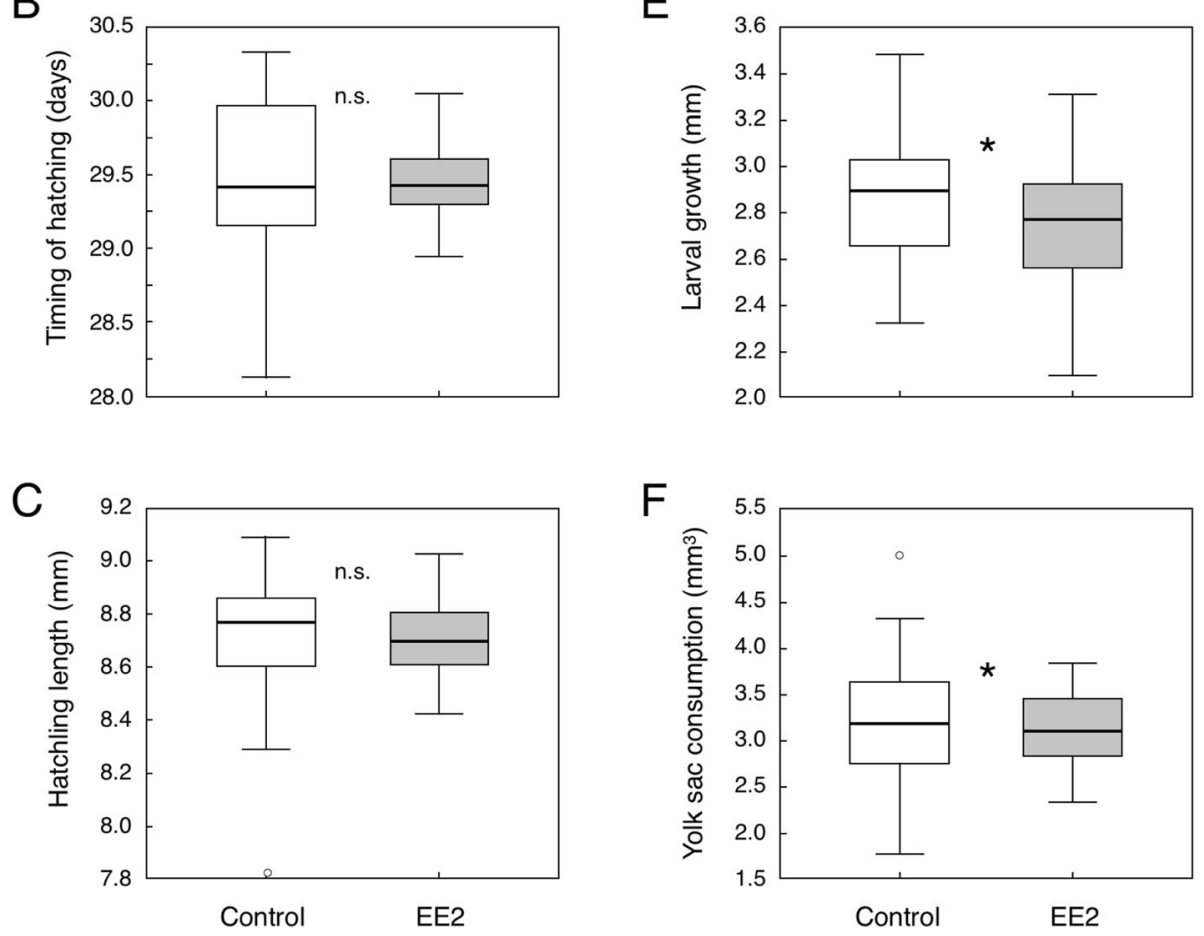

Fig. 2 The effects of a one-dose exposure to $1 \mathrm{ng} / \mathrm{L}$ 17a-ethynylestradiol (EE2) on embryo and larval phenotypes: a embryo survival, b time of hatching, $\mathbf{c}$ length at hatching, $\mathbf{d}$ larval survival, e larval growth, and $\mathbf{f}$ yolk sac consumption during the first 8 days after hatching. Tukey outlier boxplots with quartiles, whiskers, and outliers are based on 40 family means per treatment, ${ }^{*}=p<0.05$, n.s. $=$ not significant. See Tables 1 and 2 for statistics

Guttry, Wedekind, in preparation) on other samples of the same 40 families revealed genetic variation in the tolerance to infection by a bacterium, and (iv) singlyreared salmonid embryos are sensitive indicators of environmental stress, and studies based on comparable breeding designs have demonstrated additive genetic variance for the tolerance to other types of stressors, including other types of pollutants [58, 59], pathogens [60] or even water-borne cues linked to infection [61].

The finding of no significant additive genetic variance for tolerance to EE2 pollution in grayling is in sharp contrast to the findings of Brazzola et al. [22] on lakespawning whitefish. However, our findings correspond well with the ones of Marques da Cunha et al. [11] who used a similar experimental protocol to test for this type of genetic variation in 7 genetically distinct populations of river-spawning brown trout and found none (in a total sample size of 7302 singly embryos, i.e. a type II error was also unlikely in their case). Taken together, these observations support the view that the appearance of the novel stressor EE2 has induced evolution and thereby used up the corresponding additive genetic variance in river-spawning salmonid that are exposed to the pollutant, while lake-spawning salmonids who are less exposed still have a strong potential to evolve rapidly to EE2. However, alternative explanations are possible. Future studies could therefore compare exposed and nonexposed populations of the same species (if at all possible, given human population density and the finding that very low doses of EE2 can induce selection), add 
analogous tests on further river-or lake-spawning salmonids, or test for signatures of selection in the EE2 response pathways [62, 63].

As far as we know, there exist no measurements of estrogenic pollution around the spawning ground of our study population. However, this spawning ground is located in the river Aare within a city of more than 40,000 inhabitants, a large sewage treatment plant about $4 \mathrm{~km}$ downstream, and several nearby villages (with several thousand inhabitants each) upstream. The sewage treatment process typically removes only about two thirds of the EE2 [8], and exposure to EE2 is therefore likely in rivers of the Swiss Plateau $[8,64]$. Marques da Cunha et al. [11] sampled brown trout from 7 different streams (the river Aare and 6 tributaries) to test whether variation in estrogenic pollution creates population differences in toxicity of EE2. They found population differences in various embryo and larval traits, but none in the reaction to EE2. They argued that very low concentrations on EE2 and exposure during only short periods can cause selection and hence induce rapid evolution. The hypothesis is supported by the observation that the $2 \mathrm{pg}$ EE2 in the aqueous exposure seemed to be continuously taken up by the embryo (about $80 \%$ within 4 weeks) while the concentration remained constant in empty plates [11]. This suggests that salmonid eggs take up EE2 at concentrations that are far lower than the 1 $\mathrm{ng} / \mathrm{L}$ that are sometimes even found in groundwater [65]. On the other side of the scale: when Brazzola et al. [22] exposed whitefish embryos to $1 \mathrm{ng} / \mathrm{L}, 10 \mathrm{ng} / \mathrm{L}$, or $100 \mathrm{ng} / \mathrm{L} \mathrm{EE2}$, increasing concentration seemed only weakly linked to increased toxicity. Similar observations were made by Duffy et al. [23] who exposed Atlantic salmon to $1.2 \mathrm{ng} / \mathrm{L}, 11.9 \mathrm{ng} / \mathrm{L}$, and $118.6 \mathrm{ng} / \mathrm{L} \mathrm{EE} 2$, respectively. We therefore argue that our one-dose aqueous exposure to $2 \mathrm{pg}$ EE2 was ecologically relevant for grayling embryos and likely to reveal additive genetic variance for tolerance, should it exist.

Our study adds the grayling to the list of salmonids whose embryos and larvae could be experimentally exposed to ecologically relevant concentrations of around $1 \mathrm{ng} / \mathrm{L}$ EE2. With the present study, at least one species of each subfamily of the Salmonidae (Coregoninae, Salmoninae, and Thymallinae) has now even been tested using the same method of applying a one-dose exposure of $2 \mathrm{pg}$ to embryos developing in $2 \mathrm{~mL}$ wells [11, 22]. Together, these studies reveal strong species-specific reactions to EE2 within the salmonids, and various amounts of additive genetic variance in the tolerance to this synthetic stressor.

\section{Conclusions}

A key question in evolutionary conservation biology is whether populations can adapt to anthropogenic stressors such as chemical pollutants. Such evolutionary responses require additive genetic variance for the susceptibility to the pollutant. Continuous selection over several generations is then expected to deplete such genetic variance but also reduce the toxicity of the pollutant. We tested the susceptibility of a river-spawning grayling population to EE2 and found that a low and ecologically relevant concentration did not induce embryo mortality as it did in some lake-spawning salmonids. However, EE2 was still toxic because it reduced larval growth. We found additive genetic variance for fitness-relevant traits, but no significant genetic variation that would enable the population to adapt to EE2. The low toxicity and the lack of genetic variance for the susceptibility to EE2 support the hypothesis that the marked launch of contraceptive pills and the associated pollution of rivers has induced rapid evolution in river-spawning grayling.

\section{Abbreviations \\ AIC: Akaike's information criteria; EE2: 17alpha-ethynylestradiol; GLMM: Generalized linear mixed model; LMM: Linear mixed model: LRT: Likelihood ratio test; $N_{e}$ : Genetically effective population size}

\section{Acknowledgements}

We would like to thank B. Bracher, U. Gutmann, C. Küng, R. Mani, and T. Vuille from the Fishery Inspectorate Bern for permissions, discussion, and assistance in the field, L. Benaroyo, T. Bösch, A. Buser, I. Castro, P. Christe, J. Kast, D. Nusbaumer, C. Primmer, O. Selmoni, A. Uppal, E. Vermeirssen, L. Wilkins and D. Zeugin for assistance and/or discussion, and two reviewers for helpful comments.

\section{Authors' contributions}

LMC and CW designed the experiment. LMC, DM, and CW performed the field work (i.e., adult sampling, in vitro fertilizations) and distributed the fertilized eggs to 24-well plates. LMC and DM did the treatment. DM monitored hatching and determined all growth parameters. LMC and CW analyzed the data and wrote the manuscript that was critically revised by all other authors. All authors read and approved the final manuscript.

\section{Funding}

The study was funded by the Swiss National Science Foundation (31003A_159579 and 31003A_182265).

\section{Availability of data and materials}

The data used in this study are available from the Dryad Digital Repository: https://doi.org/10.5061/dryad.7wm37pvp0

\section{Ethics approval and consent to participate \\ The experimental breeding and raising of embryos were approved by the Fishery Inspectorate of the Bern canton. The tissue sampling was approved by the Veterinary Office of the Bern canton (approval number BE188/14). The invasive fin biopsy was classified by this Veterinary Office as degree of severity 1 (on the scale from 0 to 3 ) while the catching of wild adults, the keeping of these animals for some days at the Fischereistützpunkt Reutigen, and the collection of gametes was part of the cantonal routine breeding for the annual stocking and was therefore not considered part of the experiment.}

Consent for publication Not applicable.

\section{Competing interests}

The authors declare that they have no competing interests. 
Received: 19 June 2019 Accepted: 9 December 2019 Published online: 16 December 2019

\section{References}

1. Chèvre N. Pharmaceuticals in surface waters: sources, behavior, ecological risk, and possible solutions. Case study of Lake Geneva, Switzerland. WIRES Water. 2014;1(1):69-86

2. Schoenborn A, Kunz P, Koster M. Estrogenic activity in drainage water: a field study on a Swiss cattle pasture. Environ Sci Eur. 2015;27(1):1-15.

3. Burkhardt-Holm P, Segner H, Burki R, Peter A, Schubert S, Suter MJ-F, Borsuk ME. Estrogenic endocrine disruption in Switzerland: assessment of fish exposure and effects. CHIMIA. 2008;62(5):376-82.

4. Elliott JM. Quantitative ecology and the brown trout. Oxford: Oxford University Press; 1994.

5. Finn RN. The physiology and toxicology of salmonid eggs and larvae in relation to water quality criteria. Aquat Toxicol. 2007;81(4):337-54.

6. Ternes TA, Kreckel P, Mueller J. Behaviour and occurrence of estrogens in municipal sewage treatment plants--II. Aerobic batch experiments with activated sludge. Sci Total Env. 1999;225(1-2):91-9.

7. Jürgens MD, Holthaus Kl, Johnson AC, Smith JJ, Hetheridge M, Williams RJ. The potential for estradiol and ethinylestradiol degradation in English rivers. Environ Toxicol Chem. 2002;21(3):480-8.

8. Johnson AC, Dumont E, Williams RJ, Oldenkamp R, Cisowska I, Sumpter JP. Do concentrations of ethinylestradiol, estradiol, and diclofenac in European rivers exceed proposed EU environmental quality standards? Environ Sci Technol. 2013;47(21):12297-304.

9. Leet JK, Gall HE, Sepulveda MS. A review of studies on androgen and estrogen exposure in fish early life stages: effects on gene and hormonal control of sexual differentiation. J Appl Toxicol. 2011;31(5):379-98.

10. Tiedeken EJ, Tahar A, McHugh B, Rowan NJ. Monitoring, sources, receptors, and control measures for three European Union watch list substances of emerging concern in receiving waters - a 20 year systematic review. Sci Total Env. 2017:574:1140-63.

11. Marques da Cunha L, Uppal A, Seddon E, Nusbaumer D, ELM V, Wedekind C. No additive genetic variance for tolerance to ethynylestradiol exposure in natural populations of brown trout (Salmo trutta). Evol Appl. 2019:12(5):940-50.

12. Grzybowski W, Szydlowski J. The impact of chromophoric dissolved organic matter on the photodegradation of 17 alpha-ethinylestradiol (EE2) in natural waters. Chemosphere. 2014;111:13-7.

13. Moschet C, Gotz C, Longree P, Hollender J, Singer H. Multi-level approach for the integrated assessment of polar organic micropollutants in an international lake catchment: the example of Lake Constance. Environ Sci Technol. 2013:47(13):7028-36.

14. Wang YQ, Li YW, Chen QL, Liu ZH. Long-term exposure of xenoestrogens with environmental relevant concentrations disrupted spermatogenesis of zebrafish through altering sex hormone balance, stimulating germ cell proliferation, meiosis and enhancing apoptosis. Environm Pollut. 2019;244:486-94.

15. Bailey C, von Siebenthal EW, Rehberger K, Segner H. Transcriptomic analysis of the impacts of ethinylestradiol (EE2) and its consequences for proliferative kidney disease outcome in rainbow trout (Oncorhynchus mykiss). Comp Biochem Physiol C Toxicol Pharmacol. 2019;222:31-48.

16. Runnalls TJ, Beresford N, Kugathas S, Margiotta-Casaluci L, Scholze M, Scott AP, Sumpter JP. From single chemicals to mixtures--reproductive effects of levonorgestrel and ethinylestradiol on the fathead minnow. Aquat Toxicol. 2015:169:152-67.

17. Jackson LM, Klerks PL. Impact of long-term exposure to 17-Ethinylestradiol in the live-bearing fish Heterandria formosa. Arch Environ Contam Toxicol. 2019;77(1):51-61.

18. Kidd KA, Paterson MJ, Rennie MD, Podemski CL, Findlay DL, Blanchfield PJ, Liber K. Direct and indirect responses of a freshwater food web to a potent synthetic oestrogen. Phil Trans R Soc B. 2014;369(1656):20130578.

19. Blanchfield PJ, Kidd KA, Docker MF, Palace VP, Park BJ, Postma LD. Recovery of a wild fish population from whole-lake additions of a synthetic estrogen. Environ Sci Technol. 2015;49(5):3136-44.

20. Wedekind C. Demographic and genetic consequences of disturbed sex determination. Phil Trans R Soc B. 2017;372(1729):20160326.

21. Aris AZ, Shamsuddin AS, Praveena SM. Occurrence of 17alpha-ethynylestradiol (EE2) in the environment and effect on exposed biota: a review. Environ Int. 2014; 69:104-19.
22. Brazzola G, Chèvre N, Wedekind C. Additive genetic variation for tolerance to estrogen pollution in natural populations of Alpine whitefish (Coregonus sp., Salmonidae). Evol Appl. 2014;7(9):1084-93.

23. Duffy TA, Iwanowicz LR, McCormick SD. Comparative responses to endocrine disrupting compounds in early life stages of Atlantic salmon, Salmo salar. Aquat Toxicol. 2014;152:1-10.

24. Reid NM, Proestou DA, Clark BW, Warren WC, Colbourne JK, Shaw JR, Karchner SI, Hahn ME, Nacci D, Oleksiak MF, et al. The genomic landscape of rapid repeated evolutionary adaptation to toxic pollution in wild fish. Science. 2016;354(6317):1305-8.

25. Hendry AP, Gotanda KM, Svensson El. Human influences on evolution, and the ecological and societal consequences introduction. Phil Trans R Soc B. 2017:372(1712):20160028.

26. Lynch M, Walsh B. Genetics and analysis of quantitative traits. Sinauer Associates Inc: Sunderland; 1998.

27. Wedekind C, Küng C. Shift of spawning season and effects of climate warming on developmental stages of a grayling (Salmonidae). Cons Biol. 2010;24(5):1418-23.

28. Wedekind C, Evanno G, Székely T, Pompini M, Darbellay O, Guthruf J. Persistent unequal sex ratio in a population of grayling (Salmonidae) and possible role of temperature increase. Cons Biol. 2013;27(1):229-34.

29. Wood JL, Tezel D, Joyal D, Fraser DJ. Population size is weakly related to quantitative genetic variation and trait differentiation in a stream fish. Evolution. 2015;69(9):2303-18.

30. Wood JLA, Yates MC, Fraser DJ. Are heritability and selection related to population size in nature? Meta-analysis and conservation implications. Evol Appl. 2016;9(5):640-57

31. Selmoni OM, Maitre D, Roux J, Wilkins LGE, Marques da Cunha L, ELM V Knörr S, Robinson-Rechavi M, Wedekind C. Sex-specific changes in gene expression in response to estrogen pollution around the onset of sex differentiation in grayling (Salmonidae). BMC Genomics. 2019;20(1):583.

32. OECD. Guideline for testing of chemicals 203 (fish acute toxicity test). Paris: OECD Publishing; 1992.

33. von Siebenthal BA, Jacob A, Wedekind C. Tolerance of whitefish embryos to Pseudomonas fluorescens linked to genetic and maternal effects, and reduced by previous exposure. Fish Shellfish Immunol. 2009;26(3):531-5.

34. Maitre D, Selmoni OM, Uppal A, Marques da Cunha L, LGE W, Roux J, Mobley KB, Castro I, Knörr S, Robinson-Rechavi M, et al. Sex differentiation in grayling (Salmonidae) goes through an all-male stage and is delayed in genetic males who instead grow faster. Sci Rep. 2017;7:15024.

35. Jensen LF, Hansen MM, Pertoldi C, Holdensgaard G, Mensberg KLD, Loeschcke V. Local adaptation in brown trout early life-history traits: implications for climate change adaptability. Proc R Soc B Biol Sci. 2008; 275(1653):2859-68.

36. Bates D, Machler M, Bolker BM, Walker SC. Fitting linear mixed-effects models using Ime4. J Stat Softw. 2015;67(1):1-48

37. R Development Core team. R: a language and environment for statistical computing. Vienna: R Foundation for statistical Computing; 2015.

38. Morthorst JE, Korsgaard B, Bjerregaard P. Severe malformations of eelpout (Zoarces viviparus) fry are induced by maternal estrogenic exposure during early embryogenesis. Mar Environ Res. 2016;113:80-7.

39. Rodenas MC, Cabas I, Garcia-Alcazar A, Meseguer J, Mulero V, Garcia-Ayala A. Selective estrogen receptor modulators differentially alter the immune response of gilthead seabream juveniles. Fish Shellfish Immun. 2016;52:189-97.

40. Hua JH, Han J, Wang XF, Guo YY, Zhou BS. The binary mixtures of megestrol acetate and 17 alpha-ethynylestradiol adversely affect zebrafish reproduction. Environm Pollut. 2016;213:776-84

41. Armstrong BM, Lazorchak JM, Jensen KM, Haring HJ, Smith ME, Flick RW, Bencic DC, Biales AD. Reproductive effects in fathead minnows (Pimphales promelas) following a $21 \mathrm{~d}$ exposure to 17 alpha-ethinylestradiol. Chemosphere. 2016;144:366-73.

42. Hamilton PB, Cowx IG, Oleksiak MF, Griffiths AM, Grahn M, Stevens JR, Carvalho GR, Nicol E, Tyler CR. Population-level consequences for wild fish exposed to sublethal concentrations of chemicals - a critical review. Fish Fish. 2016;17(3):545-66.

43. Schwindt AR, Winkelman DL. Estimating the effects of 17 alpha-ethinylestradio on stochastic population growth rate of fathead minnows: a population synthesis of empirically derived vital rates. Ecotoxicology. 2016;25(7):1364-75.

44. Wedekind C, von Siebenthal B, Gingold R. The weaker points of fish acute toxicity tests and how tests on embryos can solve some issues. Environm Pollut. 2007;148(2):385-9. 
45. Pompini M, Buser AM, Thali MR, von Siebenthal BA, Nusslé S, Guduff S, Wedekind C. Temperature-induced sex reversal is not responsible for sexratio distortions in grayling Thymallus thymallus or brown trout Salmo trutta. J Fish Biol. 2013:83(2):404-11.

46. Thrupp TJ, Runnalls TJ, Scholze M, Kugathas S, Kortenkamp A, Sumpter JP. The consequences of exposure to mixtures of chemicals: something from 'nothing' and 'a lot froma little' when fish are exposed to steroid hormones. Sci Total Env. 2018;619:1482-92.

47. Segner H, Schmitt-Jansen M, Sabater S. Assessing the impact of multiple stressors on aquatic biota: the receptor's side matters. Environ Sci Technol. 2014:48(14):7690-6.

48. Segner H, Wahli T, Burkhardt-Holm P. Combined effects of parasites, climate and pollution on brown trout, Salmo trutta, in Swiss rivers. Comp Biochem Physiol A Mol Integr Physiol. 2012;163:S40.

49. Breves JP, Duffy TA, Einarsdottir IE, Bjornsson BT, McCormick SD. In vivo effects of 17 alpha-ethinylestradiol, 17 beta-estradiol and 4-nonylphenol on insulin-like growth-factor binding proteins (igfbps) in Atlantic salmon. Aquat Toxicol. 2018;203:28-39.

50. Einum S, Fleming IA. Selection against late emergence and small offspring in Atlantic salmon (Salmo salar). Evolution. 2000;54(2):628-39.

51. Skoglund H, Einum S, Forseth T, Barlaup BT. The penalty for arriving late in emerging salmonid juveniles: differences between species correspond to their interspecific competitive ability. Funct Ecol. 2012;26(1):104-11.

52. Hanif A, Bakopoulos V, Dimitriadis GJ. Maternal transfer of humoral specific and non-specific immune parameters to sea bream (Sparus aurata) larvae. Fish Shellfish Immun. 2004:17(5):411-35.

53. Wang ZP, Zhang SC, Tong Z, Li L, Wang GF. Maternal transfer and protective role of the alternative complement components in zebrafish Danio rerio. PLoS ONE. 2009;4(2):e4498.

54. Wilkins LGE, Marques da Cunha L, Glauser G, Vallat A, Wedekind C. Environmental stress linked to consumption of maternally derived carotenoids in brown trout embryos (Salmo trutta). Ecol Evol. 2017;7:5082-93.

55. Wilkins LGE, Marques da Cunha L, Menin L, Ortiz D, Vocat-Mottier V, Hobil M, Nusbaumer D, Wedekind C. Maternal allocation of carotenoids increases tolerance to bacterial infection in brown trout. Oecologia. 2017;185:351-63.

56. Marques da Cunha L, LGE W, Menin L, Ortiz D, Vocat-Mottier V, Wedekind C. Consumption of carotenoids not increased by bacterial infection in brown trout embryos (Salmo trutta). PLoS One. 2018;13(6):e0198834.

57. Moore MP, Whiteman HH, Martin RA. A mother's legacy: the strength of maternal effects in animal populations. Ecol Lett. 2019;22(10):1620-8.

58. Clark ES, Pompini M, Uppal A, Wedekind C. Genetic correlations and little genetic variance for reaction norms may limit potential for adaptation to pollution by ionic and nanoparticulate silver in a whitefish (Salmonidae). Ecol Evol. 2016;6(9):2751-62.

59. Jacob A, Evanno G, von Siebenthal BA, Grossen C, Wedekind C. Effects of different mating scenarios on embryo viability in brown trout. Mol Ecol. 2010;19(23):5296-307.

60. Clark ES, Pompini M, Marques da Cunha L, Wedekind C. Maternal and paternal contributions to pathogen resistance dependent on development stage in a whitefish. Funct Ecol. 2014:28(3):714-23.

61. Pompini M, Clark ES, Wedekind C. Pathogen-induced hatching and population-specific life-history response to waterborne cues in brown trout (Salmo trutta). Behav Ecol Sociobiol. 2013;67(4):649-56.

62. Weigand $\mathrm{H}$, Leese $\mathrm{F}$. Detecting signatures of positive selection in nonmodel species using genomic data. Zool J Linnean Soc. 2018;184(2):528-83.

63. Csillery K, Rodriguez-Verdugo A, Rellstab C, Guillaume F. Detecting the genomic signal of polygenic adaptation and the role of epistasis in evolution. Mol Ecol. 2018;27(3):606-12.

64. Zhang H, Kong FX, Yu Y, Shi XL, Zhang M, Tian HE. Assessing the combination effects of environmental estrogens in fish. Ecotoxicology. 2010; 19(8):1476-86

65. Vulliet E, Cren-Olive C. Screening of pharmaceuticals and hormones at the regional scale, in surface and groundwaters intended to human consumption. Environm Pollut. 2011;159(10):2929-34.

\section{Publisher's Note}

Springer Nature remains neutral with regard to jurisdictional claims in published maps and institutional affiliations.

\section{Ready to submit your research? Choose BMC and benefit from:}

- fast, convenient online submission

- thorough peer review by experienced researchers in your field

- rapid publication on acceptance

- support for research data, including large and complex data types

- gold Open Access which fosters wider collaboration and increased citations

- maximum visibility for your research: over $100 \mathrm{M}$ website views per year

At $\mathrm{BMC}$, research is always in progress.

Learn more biomedcentral.com/submissions 